\title{
MICROSTRUCTURE ANALYSIS AND WEAR BEHAVIOUR OF AL BASED METAL MATRIX COMPOSITE REINFORCED WITH CERAMIC PARTICLES
}

\author{
Srinivasa.K ${ }^{1}$, Devaraj.M.R ${ }^{2}$, Yathisha. $N^{3}$, Manjunath.H.S ${ }^{4}$ \\ ${ }^{1}$ Department of Mechanical Engineering, ATMECE, $13^{\text {th }}$ kilometre, bannur road, Mysore, 570028 \\ ${ }^{2}$ Department of Mechanical Engineering, ATMECE, $13^{\text {th }}$ kilometre, bannur road, Mysore, 570028 \\ ${ }^{3}$ Department of Mechanical Engineering, ATMECE, $13^{\text {th }}$ kilometre, bannur road, Mysore, 570028 \\ ${ }^{4}$ Department of Mechanical Engineering, ATMECE, $13^{\text {th }}$ kilometre, bannur road, Mysore, 570028
}

\begin{abstract}
Aluminium alloys is gathering more interest in research field because of its wide applications in aerospace and automobile industries. Aluminium alloys are used as a base metal in metal matrix composites (MMC's) with ceramic particulates as reinforcement. This improves the properties of aluminium alloys. The purpose of this paper was to study the mechanical properties of Al-Mg-SiC composites manufactured by stir casting method with varying composition of $\mathrm{SiC}(0 \%, 5 \%, 10 \%$ and $15 \%)$. Initially XRD and SEM analysis of the samples were done to study the phases present and their distribution along with idea of composition. Then hardness and wear studies were carried out to judge the surface mechanical properties of the composites prepared. It has been found from this study that percentage of reinforcement in the composite causes changes in its hardness and wear properties.
\end{abstract}

Keywords: Wear Behaviour, Metal Matrix Composite, Ceramic Particles, Microstructure analysis $* * *$

\section{INTRODUCTION}

Metal matrix composite (MMC) is engineeed combination of metal (matrix) and hard particles (reinforcement) to tailored properties. Metal matrix composites have very light weight, high strength and stiffness and exhibit greater resistance corrosion, oxidation and wear [1].

Aluminium based metal matrix composites have been one of the key research areas in materials processing field in the last few decades. Most of the research work has been dealing with aluminium matrix and $\mathrm{SiC}$ reinforcement requiring the light weight in combination of high strength and high stiffness $[4,5,6,7,15,16]$. This is because aluminium is lighter weight which is first requirement in most of the industries. In addition, it provides impressive strength improvement and the thermal expansion coefficient. The properties of $\mathrm{Al}$ matrix composites can be adjusted by using silicon carbide, carbon and boron carbides reinforcement. As a result, these materials are now being rapidly utilized in industries than traditionally used metals.

In this paper, a study on the effect of varying reinforcement $(\mathrm{SiC})$ percentage on the mechanical property of the base metal Al-Mg (LM-6) has been carried out.

\section{SPECIMEN PREPARATION}

The specimen composition is shown in Table-1.The major alloying element in this aluminium alloy is silicon $(\mathrm{Si})$. Silicon's importance in aluminium casting is that a significantly high amount (12\%) of silicon in aluminium forms a eutectic mixture which solidifies with very little thermal contraction. This greatly reduces tearing and cracks formed from stress as casting alloys cool to solidity. Silicon also significantly improves the hardness and thus wearresistance of aluminium. The other element Magnesium $(\mathrm{Mg})$ which is added to improve wettability $[3,10,11,14]$. Silicon carbide $(\mathrm{SiC})$ is used as reinforcement with varying percentage (composition-I-0\%, composition-II-5\%, composition-III-10\%, and composition-IV-15\%). Table -2 signifies the important properties of the material added.

Table 1: Material composition of the MMC

\begin{tabular}{|l|l|l|l|l|l|}
\hline $\begin{array}{l}\text { Element } \\
\mathrm{s}\end{array}$ & $\mathrm{Pb}$ & $\mathrm{Sn}$ & $\mathrm{Ti}$ & $\begin{array}{l}\mathrm{Al}(\mathrm{LM} 6 \\
)\end{array}$ & $\mathrm{SiC}$ \\
\hline $\begin{array}{l}\text { Actual } \\
\text { value } \\
(\%)\end{array}$ & 0.1 & 0.05 & 0.2 & 88.15 & $\begin{array}{l}0,5,10 \\
, 15\end{array}$ \\
\hline
\end{tabular}

\begin{tabular}{|l|l|l|l|l|l|l|l|}
\hline Elements & $\mathrm{Cu}$ & $\begin{array}{l}\mathrm{M} \\
\mathrm{g}\end{array}$ & $\mathrm{Si}$ & $\mathrm{Fe}$ & $\begin{array}{l}\mathrm{M} \\
\mathrm{n}\end{array}$ & $\mathrm{Ni}$ & $\mathrm{Zn}$ \\
\hline $\begin{array}{l}\text { Actual } \\
\text { Value } \\
(\%)\end{array}$ & 0.1 & 0.1 & $\begin{array}{l}10- \\
13\end{array}$ & 0.6 & 0.6 & 0.1 & 0.1 \\
\hline
\end{tabular}


Table I: Properties of material added

\begin{tabular}{|l|l|l|}
\hline Material & $\begin{array}{l}\text { Density } \\
\left(\mathrm{g} / \mathrm{cm}^{3}\right)\end{array}$ & $\begin{array}{l}\text { Melting Point } \\
\text { in }{ }^{\circ} \mathrm{C}\end{array}$ \\
\hline Aluminium (LM6) & 2.65 & 660 \\
\hline Silicon Carbide & 3.21 & 2730 \\
\hline Magnesium & 1.738 & 650 \\
\hline
\end{tabular}

$[2,8,9,12,13]$ Stir casting method was adapted for the preparation of the specimens. Initially the Aluminium (LM6) slabs were melted in a crucible and the temperature of the crucible was maintained at this point. This is shown in fig1.Afterthe Aluminium is melted the reinforced materials like Magnesium and Silicon Carbide is added to the molten Aluminium and it is heated above $900^{\circ} \mathrm{C}$. The molten materials is mixed with reinforced materials with the help of a mechanical stirrer and stirred thoroughly for 5 minutes at $250 \mathrm{rpm}$. This is shown in fig.2.After the material are mixed thorougly the molten metal is taken out from the crucible and poured into the preheated dies. This is shown in fig.3.

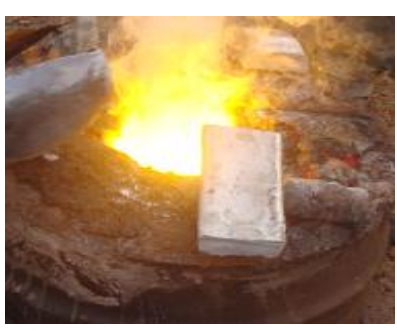

Fig.1.Melting of LM6

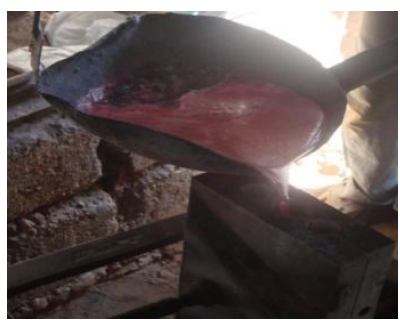

Fig.3.Pouring of molten

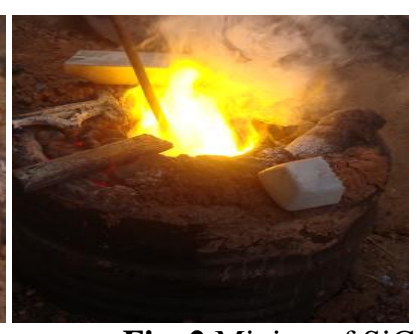

Fig. 2.Mixing of SiC

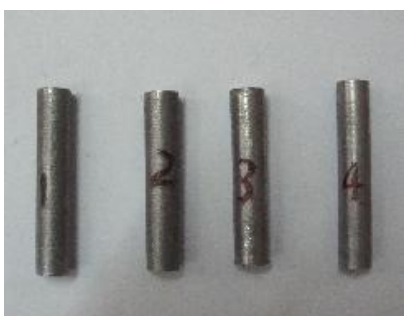

Fig.4.Wear test specimens Mixture into the die
Brinell hardness test was carried out to find the hardness of the compositions. The specimens for the hardness test were prepared as per ASTM E-10 standard.

Wear test specimens are prepared as per ASTM G-99 standard. Wear test was conducted using pin and disc apparatus. This is shown in fig-5.
The test was conducted for different disc speed sand the load on the specimen was varied.

\section{RESULTS AND DISCUSSION}

Table- 3 shows the Brinell hardness number (BHN) for all the compositions. The following empirical formulae is used determine the BHN.

$$
\mathrm{BHN}=\frac{2 \mathrm{~F}}{\pi D\left(D-\sqrt{\left.\left.D^{2-} d^{2}\right)\right)}\right.}
$$

Where,

$\mathrm{F}=$ applied force $(\mathrm{Kgf})$

$\mathrm{D}=$ diameter of the indenter in $\mathrm{mm}$

$\mathrm{d}=$ diameter of the indentation in $\mathrm{mm}$

Table 3: Brinell hardness reading for the different compositions

\begin{tabular}{|l|l|}
\hline Material & BHN \\
\hline Composition-I & 55.68 \\
\hline Composition-II & 61.47 \\
\hline Composition -III & 67.72 \\
\hline Composition-IV & 76.77 \\
\hline
\end{tabular}

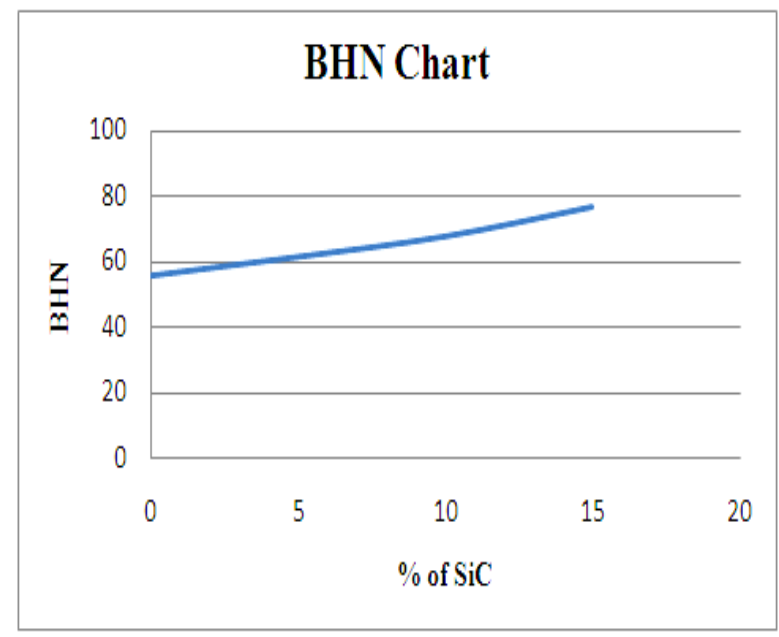

Fig.6. BHN comparison graph

Fig .6 shows the comparison graph of BHN for different compositions as mentioned earlier. It can be seen that as the $\%$ of $\mathrm{SiC}$ increases the hardness of the base metal increases.

XRD samples were taken to study the material distribution for all the four composition.Fig.7 shows the XRD reading of all the compositions.

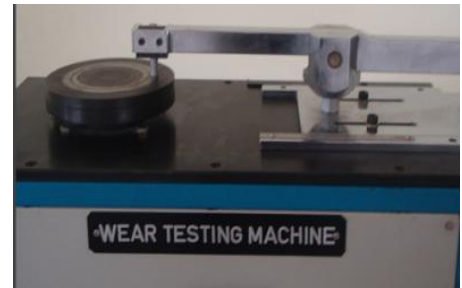

Fig.5. Pin and Disc apparatus set up 


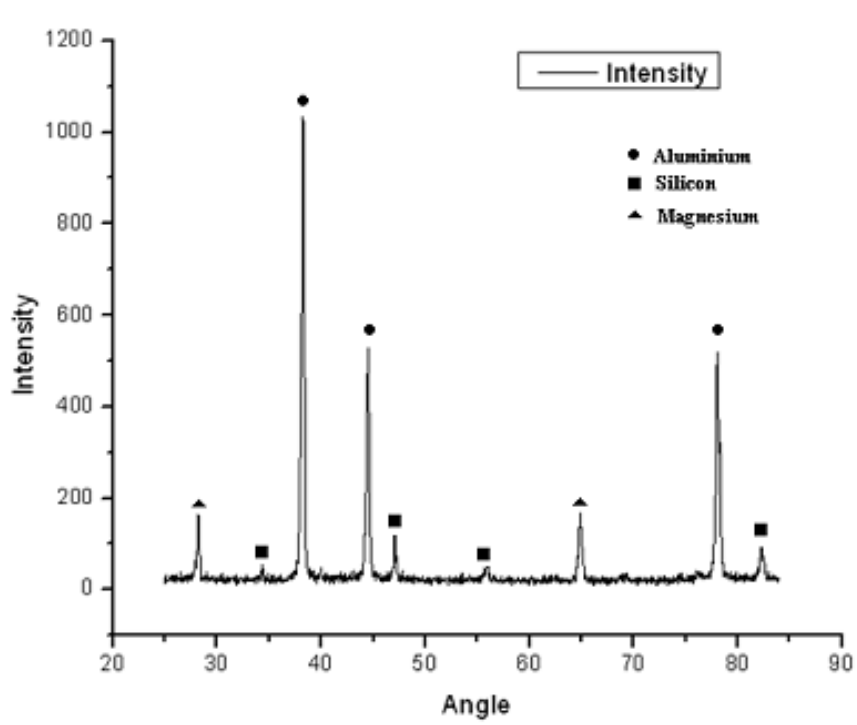

Fig.7a. Graph of intensity v/s angle for Base Metal

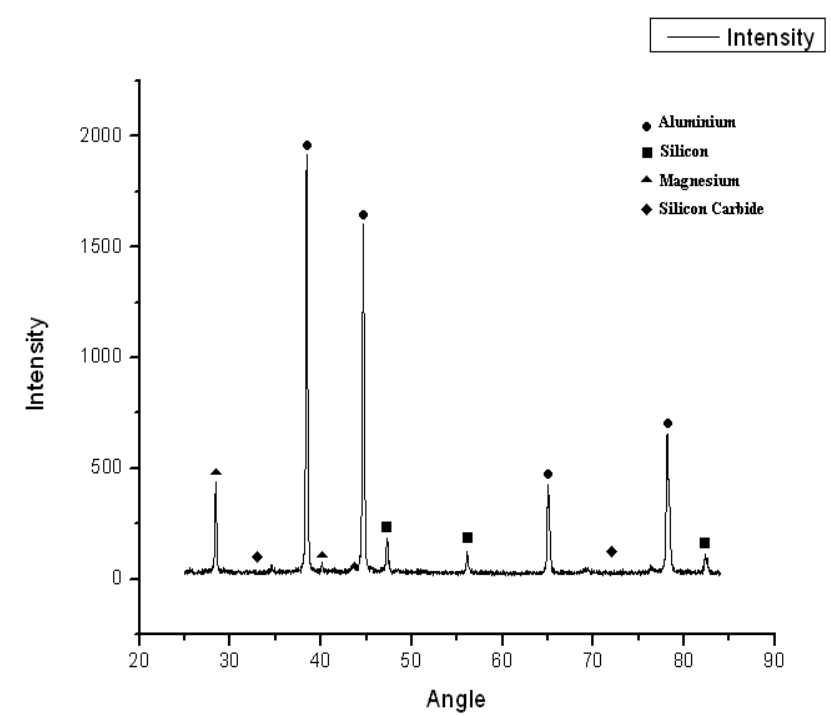

Fig.7b.Graph of intensity v/s anglefor $\mathrm{Al} 5 \% \mathrm{SiC}$

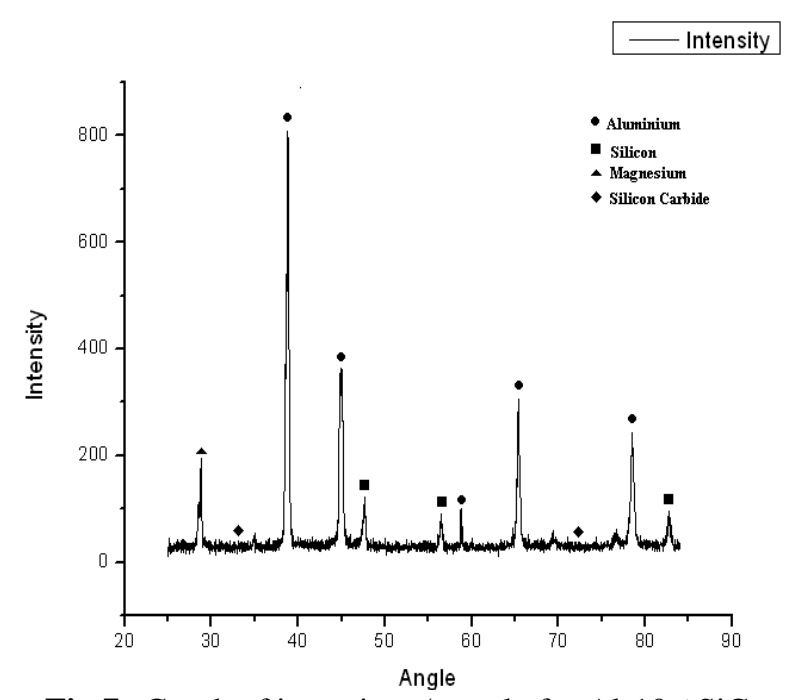

Fig.7c.Graph of intensity v/s angle for $\mathrm{Al}-10 \% \mathrm{SiC}$

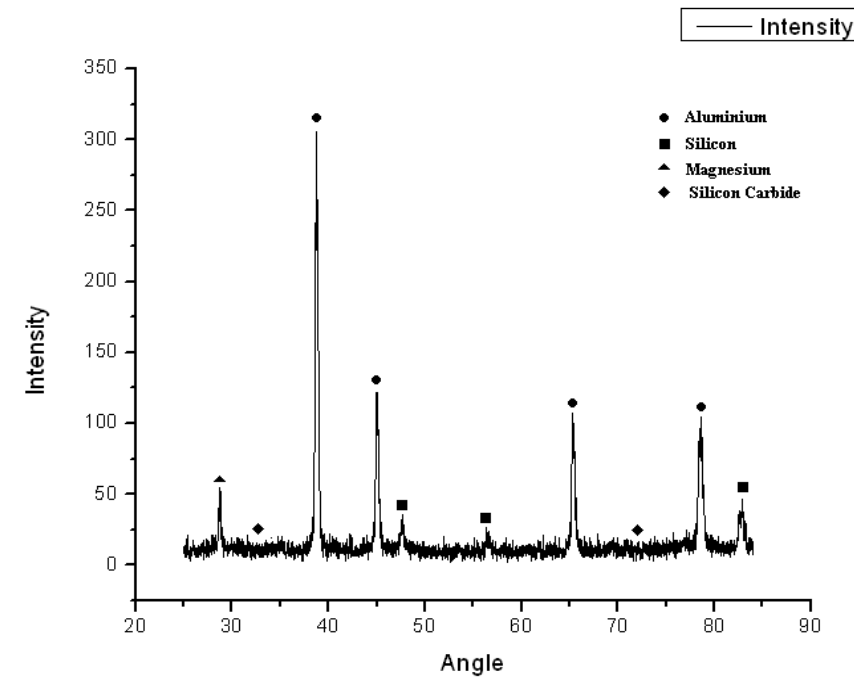

Fig.7d.Graph of intensity v/s angle for $\mathrm{Al}-15 \% \mathrm{SiC}$

It can be observed from the XRD graphs that as the reinforcement $(\mathrm{SiC})$ percentage in the base metal $(\mathrm{Al})$ increases, the intensity on aluminium decreases.

Fig- 8 shows the microstructure of all the compositions. Micro structural examination reveals nearly uniform distribution of particles.

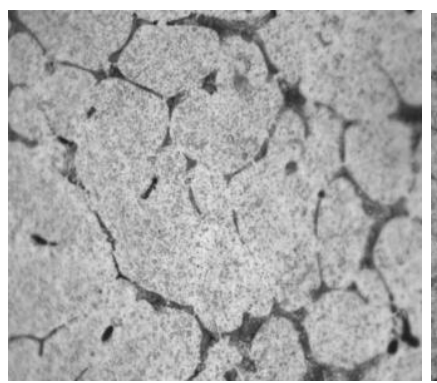

Base metal

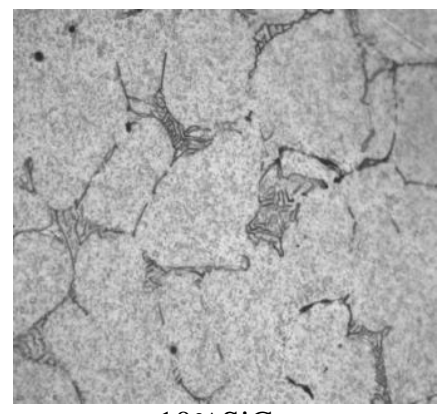

$10 \% \mathrm{SiC}$

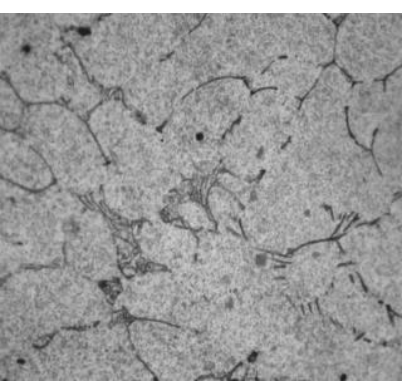

$5 \% \mathrm{SiC}$

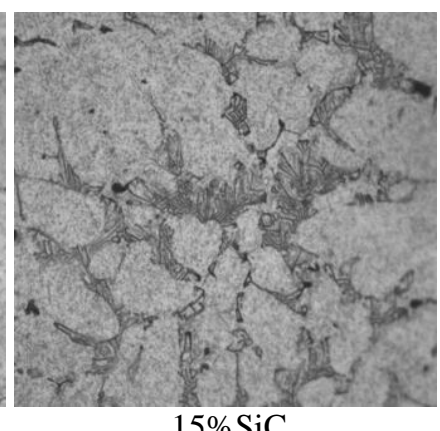

$15 \% \mathrm{SiC}$
Fig.8.Microstructure

Table $-4 \& 5$ gives the reading obtained after conducting the wear test. In this test, the rotation of the disc was varied to; 800rpm, 900rpm and 1000rpm.The load on the pin was changed to $2 \mathrm{Kg}$ and $3 \mathrm{Kg}$. The following empirical formula is used to determine the wear coefficient.

$$
\mathrm{K}=\frac{\mathrm{VXH}}{\mathrm{FX} \mathrm{S}} \mathrm{mm}^{3} / \mathrm{N}-\mathrm{m}
$$


Where,

$\mathrm{K}=$ Wear coefficient in $\mathrm{mm}^{3} / \mathrm{N}-\mathrm{m}$

$\mathrm{V}=$ Volume of Wear in $\mathrm{mm}^{3}$

$\mathrm{H}=$ Brinell hardness number

$\mathrm{F}=$ Applied Force in $\mathrm{N}$

$\mathrm{S}=$ Wear Distance in $\mathrm{mm}$

$\mathrm{S}=2 \pi \mathrm{RNT}$.

$\mathrm{N}=$ Speed in $\mathrm{rpm}$.

$\mathrm{T}=$ Time in $\mathrm{min}$.

Table 4: Wear test reading and results for $2 \mathrm{~kg}$ load on the pin

\begin{tabular}{|c|c|c|c|c|}
\hline \multirow{2}{*}{$\begin{array}{l}\text { Speed N } \\
\text { (rpm) }\end{array}$} & \multicolumn{4}{|c|}{ Wear $(\mu \mathrm{m})$} \\
\hline & $\begin{array}{l}\text { Base } \\
\text { metal }\end{array}$ & $5 \% \mathrm{SiC}$ & $10 \% \mathrm{SiC}$ & $15 \% \mathrm{SiC}$ \\
\hline 800 & 110 & 102 & 82 & 70 \\
\hline 900 & 120 & 105 & 85 & 75 \\
\hline 1000 & 180 & 117 & 97 & 81 \\
\hline \multirow{2}{*}{$\begin{array}{l}\text { Speed N } \\
(\mathrm{rpm})\end{array}$} & \multicolumn{4}{|c|}{ Wear coefficient } \\
\hline & $\begin{array}{l}\text { Base } \\
\text { metal }\end{array}$ & $5 \% \mathrm{SiC}$ & $10 \% \mathrm{SiC}$ & $15 \% \mathrm{SiC}$ \\
\hline 800 & $1.951 \mathrm{e}-5$ & $1.997 \mathrm{e}-5$ & $1.7689 \mathrm{e}-5$ & $1.7119 \mathrm{e}-5$ \\
\hline 900 & $1.892 \mathrm{e}-5$ & $1.828 \mathrm{e}-5$ & $1.629 \mathrm{e}-5$ & $1.630 \mathrm{e}-5$ \\
\hline 1000 & $2.554 \mathrm{e}-5$ & $1.833 \mathrm{e}-5$ & $1.674 \mathrm{e}-5$ & $1.585 e-5$ \\
\hline
\end{tabular}

Table 5: Wear test reading and results for $3 \mathrm{~kg}$ load on the pin

\begin{tabular}{|l|l|l|l|l|}
\hline \multirow{2}{*}{$\begin{array}{l}\text { Speed N } \\
(\mathrm{rpm})\end{array}$} & \multicolumn{4}{|l|}{ Wear $(\mu \mathrm{m})$} \\
\cline { 2 - 5 } & $\begin{array}{l}\text { Base } \\
\text { metal }\end{array}$ & $5 \% \mathrm{SiC}$ & $10 \% \mathrm{SiC}$ & $15 \% \mathrm{SiC}$ \\
\hline 800 & 132 & 126 & 102 & 74 \\
\hline 900 & 140 & 130 & 110 & 80 \\
\hline 1000 & 155 & 142 & 121 & 96 \\
\hline \multirow{2}{*}{$\begin{array}{l}\text { Speed N } \\
(\mathrm{rpm})\end{array}$} & Wear coefficient \\
\cline { 2 - 5 } & $\begin{array}{l}\text { Base } \\
\text { metal }\end{array}$ & $5 \% \mathrm{SiC}$ & $10 \% \mathrm{SiC}$ & $15 \% \mathrm{SiC}$ \\
\hline 800 & $1.561 \mathrm{e}-5$ & $1.645 \mathrm{e}-5$ & $1.467 \mathrm{e}-5$ & $1.207 \mathrm{e}-5$ \\
\hline 900 & $1.472 \mathrm{e}-5$ & $1.508 \mathrm{e}-5$ & $1.407 \mathrm{e}-5$ & $1.159 \mathrm{e}-5$ \\
\hline 1000 & $1.466 \mathrm{e}-5$ & $1.483 \mathrm{e}-5$ & $1.392 \mathrm{e}-5$ & $1.252 \mathrm{e}-5$ \\
\hline
\end{tabular}

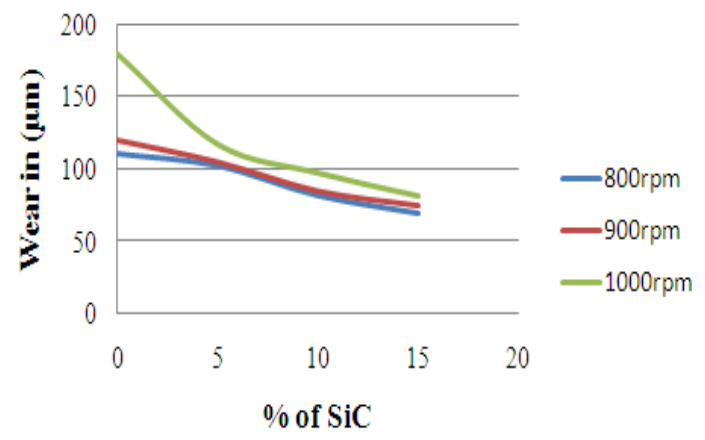

(a)

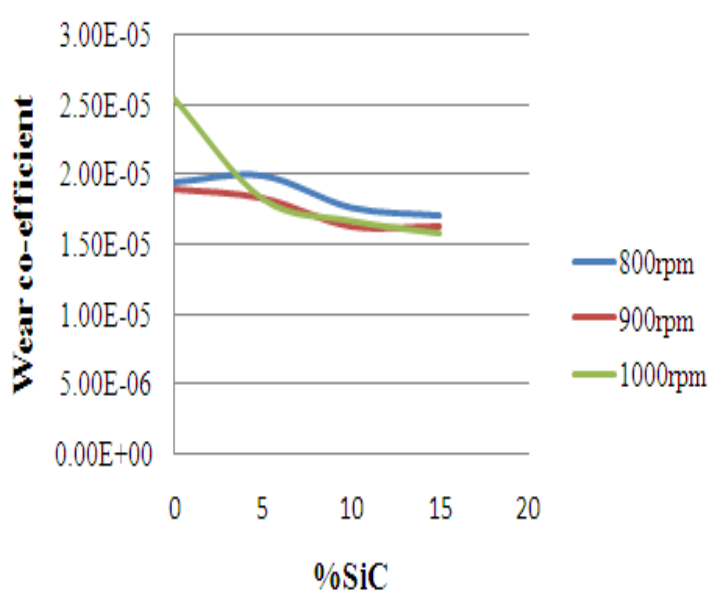

(b)

Fig.9.Comparison graph for constant $2 \mathrm{Kg}$ on the pin (a) Wear v/s \% SiC (b) Wear co-efficient v/s \% SiC

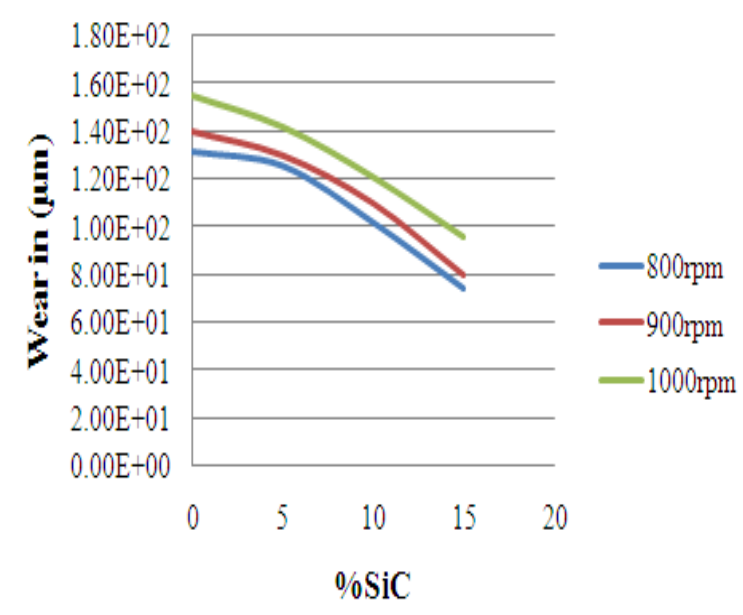

(a)

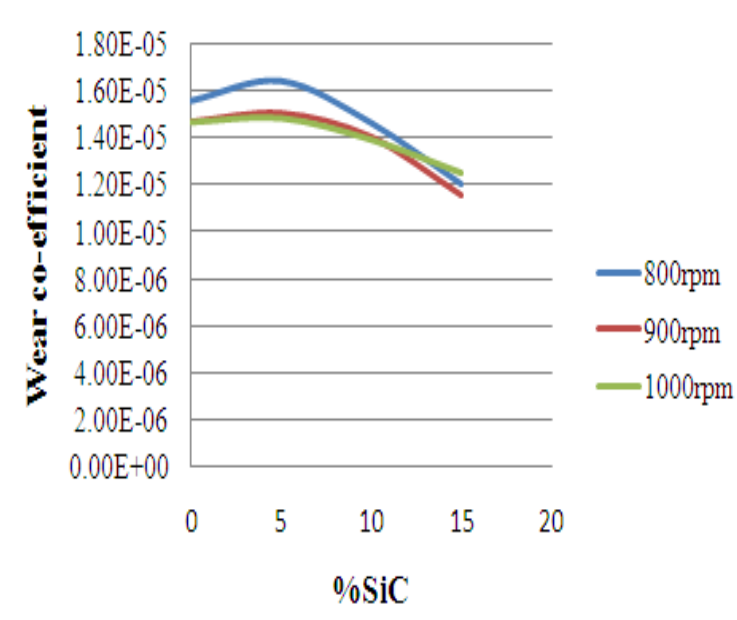

(b)

Fig.10.Comparison graph for constant $3 \mathrm{Kg}$ on the pin (a) Wear v/s \% SiC (b) Wear co-efficient v/s \% SiC 


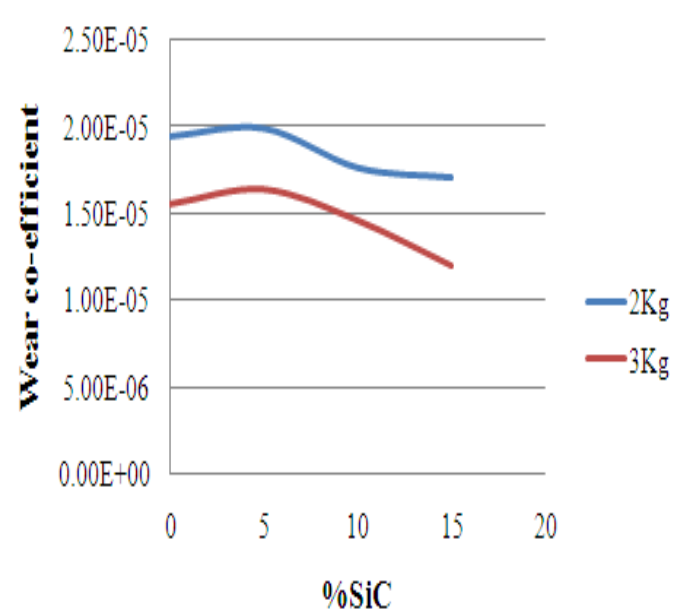

(a)

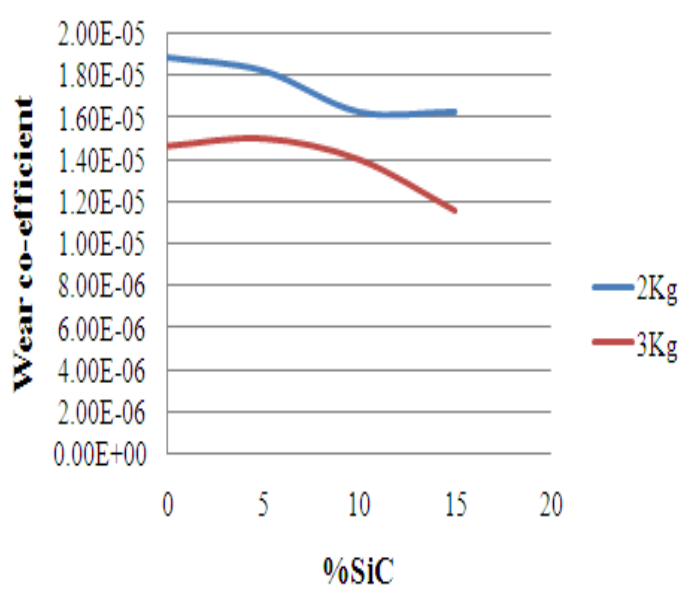

(b)

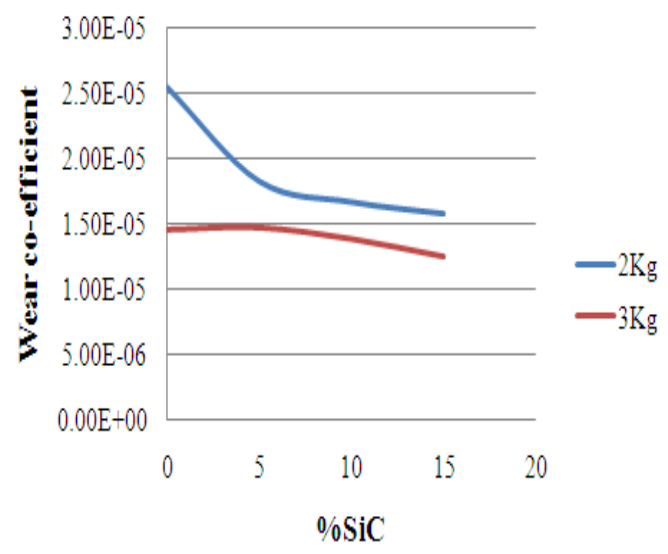

(c)

Fig.11.Comparison graph for constant Disc speed with respect to Wear co-efficient $\mathrm{v} / \mathrm{s} \% \mathrm{SiC}$ (a) $800 \mathrm{rpm}$ (b) 900rpm(c) $1000 \mathrm{rpm}$

From fig. $9 \& 10$ it can be found that as the sliding speed increases the wear slightly increases. As the percentage reinforcement in the base metal increases, the wear resistance of the material increases. From fig. 11, it can be seen that, wear resistance also depends on the load applied on the pin. Higher the load on the pin causes more wear. The sliding speed has less influence on wear rate.

\section{CONCLUSIONS}

The purpose of this paper was to develop the aluminium based composites, reinforced with $\mathrm{SiC}$ paticulate. The production was pursued through the stir casting method. Four composition of Al-SiC were melted and casted. Microstructure, hardness and wear characteristics were carried out

1. It is possible to produce composites with varying volume fractions of silicon carbide with pure aluminium.

2. X-ray diffractive analysis was carried out for all composites. Analysis confirms that $\mathrm{SiCis}$ present in the samples.

3. It is revealed from micro structural analysis that, the distribution of $\mathrm{SiC}$ was uniform.

4. The hardness of all composites were calculated and found that the hardness increases with increasing $\mathrm{SiC}$.

5. The wear coefficient decreases with the increase in SiC particulate for different load and sliding speeds.

6. It is also found that sliding distance and applied load has greater influence on wear.

\section{REFERENCES}

[1] M.J. Koczak, S.C. Khatri, J.E. Allison and M.G. Bader, "Fundamentals of Metal Matrix Composites", Metallurgical and Materials Transactions A, 1993, P.297.

[2] Sudheer Reddy, P.G. Mukunda and H.SureshHebbar, "An attempt to understand Stir Casting Process". ICAME-2007.

[3] NiyasSalim, Arun.M and Anum Kumar "Effect of $M g$ Enhancement in the Microstructure and Mechanical Properties of AC2A Aluminium Alloy"IJRET.Vol.2,issue2,Feb 2014,139-148,2014

[4] Suryanarayan.K, R.Praveen and S. Raghuraman "Silicon Carbide Reinforced Aluminium Metal Matrix Composite for Aerospace Application". IJIRSET, Vol. 2, Issue 11, November 2013.

[5] T.V.Christy, N. Murugan and S. Kumar, "A Comparative Study on the Microstructures and Mechanical Properties of Al 6061 Alloy and the MMC Al 6061/TiB2/12",JMMCE Vol. 9, No.1, PP. 57-65, 2010.

[6] RupaDasgupta, “Aluminium Alloy-Based Metal Matrix Composites: A Potential Material for Wear Resistant Applications", Volume 2012 (2012), Article ID 594573.

[7] Changwook Son, Ikwoo Kim Park, "Microstructure and Mechanical properties of reaction squeeze cast hybrid aluminium matrix composites". J. of Composite Materials. Vol.35. No. 17, 2001.

[8] W.Zhou, Z.M.Xu, "Casting of SiC reinforced metal matrix composites". J. of Material Processing Technology. Vol.63, 1999, pp.358-363. 
[9] B.P. Samal, S.C. Panigrahi, B. Sarangi "Use of Modified Stir Casting Technique to Produce Metal Matrix Composites" IJETR, Volume-1, Issue-9, November 2013.

[10] ErcanCandan, Helen V. Atkinson, YunusTuren, Iulia Salaoru and SennurCandan, "Wettability of Aluminium-Magnesium Alloys on Silicon Carbide Substrates", JACS,Volume 94, Issue 3, Pages 867874, March 2011.

[11] B.C. Pai, GeethaRamani, R.M. Pillai, and K.G.Satyanarayana, "Role of Magnesium in cast Aluminium alloy matrix composites", J.Materials science, Volume 30, Issue 8, PP 1903-1911.

[12] Rajesh Kumar, GangaramBhandare, Parashuram M. Sonawane, "Preparation of Aluminium Matrix Composite by Using Stir Casting Method", IJEAT, Vol-3, Issue-2, Dec-2013.

[13] ManojSingla, "Development of Aluminium based Silicon carbide Particulate Metal Matrix Composite”,JMMCE,Vol-8,No.6,pp-455-467,2009

[14] D.J.Lloyd, "Particle Reinforced Aluminium and Magnesium matrix Composites", International Materials Review,Vol-39,1994.

[15] H. Holzer, Th. Schmitt, "AlSiC for thermal management applications", PCIM Europe,3(1999), 24-25.

[16] B.E. Novich and R.W. Adams, "Aluminum/Silicon Carbide (AlSiC) Metal Matrix Composites For Advanced Packaging Applications" ,Proceedings of the 1995International Electronics Packaging Conference, IEPS, San Diego CA, September 2427,1995, pp 220-227. 